\title{
PENERAPAN METODE UNIFIED APPROACH PADA SISTEM INFORMASI TRAINING RECORD PT. BRIDGESTONE TIRE INDONESIA
}

\author{
Dicky Hariyanto $^{1}$, Rahmat Tri Yunandar ${ }^{2}$, Lily Ciptaningrum ${ }^{3}$ \\ ${ }^{123}$ Sistem Informasi, Universitas Bina Sarana Informatika \\ Indonesia \\ E-Mail: dicky.dkh@bsi.ac.id
}

\begin{abstract}
To support the workers get effectiveness and efficiencyin their job at the company, normally a company facilitating the development of job training for employees being creative, how to think, how to act, knowledge, skills, and work ethic. The training record system currently in use at PT Bridgestone Tire Indonesia (BSIN) can still work, but less efficient because there are some things that cannot be accessed on the page. For the examples, anyone who has been training on the theme to be searched, and when retrieving data from training record into Excel is very messy.For this reason, this journal is written to discuss the design of training record information systems that will renew the appearance of the training record pages that already existed and will cover pre-existing deficiencies. The design of this information system is a solution to the existing problem, and with the design of this new information system the company activities related to the training record can run effectively, efficiently, and smoothly.
\end{abstract}

\section{Keywords:}

Information System Design, Training Record, Training Archive System

\begin{abstract}
Abstrak
Untuk membantu tenaga kerja memperoleh efektifitas dan efisiensi dalam pekerjaan di perusahaan, biasanya perusahaan memfasilitasi pelatihan kerja untuk pengembangan kreatifitas, cara berpikir, cara bertindak, ilmu, keterampilan, dan sikap kerja. Sistem training record yang saat ini dilakukan oleh PT Bridgestone Tire Indonesia (BSIN) masih bisa berjalan, namun kurang efektif karena masih menggunakan catatan dalam bentuk file Microsoft Excel yang disimpan di sebuah perangkat komputer dari bagian pelatihan, hal tersebut tentunya akan menjadi kendala bagi perusahaan yang ingin mengetahui secara lengkap catatan pelatihan apa saja yang sudah diikuti dan hasil pelatihan oleh seorang karyawan tersebut.Untuk meminimalkan kesalahan informasi, penelitian ini membahas mengenai pembuatan sebuah sistem informasi training record yang akan meningkatkan keakuratan informasi untuk pengambilan keputusan yang tepat.
\end{abstract}

\section{Kata Kunci:}

Perancangan Sistem Informasi,Training Record, Sistem Arsip Training 


\section{Pendahuluan}

Seiring dengan pesatnya perkembangan teknologi di era revolusi industry 4.0 saat sekarang ini yang semakin menuntut kualitas yang dihasilkan dari suatu kebutuhan data atau informasi yang secara cepat dan akurat serta dengan memperhitungkan tingkat efektifitas dan efisiensi dalam prosesnya, maka dibutuhkan terobosan baru berupa system informasi guna menjawab permasalahan tersebut terutama yang berhubungan dalam pengolahan data kearsipan. Arsip digunakan sebagai salah satu sumber informasi untuk menunjang proses kegiatan administrasi dan manajemen sebuah perusahaan atau instansi. Semua kegiatan yang dilakukan oleh instansi tersebut akan menjadi arsip yang merupakan bukti dan dokumentasi atau memori bagi instansi tersebut. (Simangunsong, 2018)

Arsip yang akan didigitalisasi berupa rekam jejak kompetensi perkembangan karyawan dari hasil pelatihan (training). Dan untuk membantu tenaga kerja di perusahaan, biasanya perusahaan memfasilitasi pelatihan kerja, metode yang dikembangkan dalam pelatihan kerja ini berguna untuk pengembangan kreatifitas, cara berpikir, cara bertindak, ilmu, keterampilan, dan sikap kerja. Dari training atau pelatihan kerja ini, terdapat evaluasi training untuk memeriksa apakah peserta mempraktikkan pengetahuannya di tempat kerja. (Sutikno, 2018).

Sistemtrainingrecord yang saat ini digunakan di PT Bridgestone Tire Indonesia (BSIN) masih bisa berjalan, namun kurang efisien karena ada beberapa hal yang belum bisa diakses pada halaman. Contohnya, siapa saja yang sudah melakukan pelatihan pada tema yang akan dicari, dan saat mengambil data dari trainingrecord ke dalam data Excel masih sangat berantakan. (Herdiansyah 2019)

Penelitian Fatmawati, dkk (2018) meneliti yang berkaitan tentang pembahasan tentang perancangan sistem kearsiapan (Earchive) berfokus pada pengolahan data penjualan, katalog dan marketing berbasis web. Dalam penelitian tersebut digunakan metode pendekatan Model Waterfall.

Penelitian lainnya yaitu Mahmudah S, dkk (2019) membangun system informasi manajemen pengarsipan surat masuk dan surat keluar pada studi kasus MA Darul Ihya Bogor. Dalam metode penelitian yang digunakan SDLC (System Development Lifa Cycle) model Waterfall.

Berdasarkan permasalahan dan kebutuhan yang telah dijelaskan maka terdapat isu yang menjadi dasar dari penelitan kali ini. Adalah metode SDLC (System Development Lifa Cycle) model Waterfall yang telah diteliti sebelumnya memiliki keterbatasan dalam standarisasi 
pemodelan pada design dan struktur suatu kerangka pengembangan system informasi. Oleh karena itu penelitian ini membahas tentang suatu pendekatan dalam pengembangan system informasi melalui Unified Approch Model dimana lebih mengutamakan pendekatan berbasis object pada kerangka dan sistematika kerja, serta kesinambungan antara design model dan penerapan pada pemogramman sebagai standarisasi dalam pengembangan program. Tujuan dari penelitian ini adalah memberikan gambaran yang lebih nyata pada tiap-tiap proses pengembangan sistem informasi serta memungkinkan untuk secara sistematis mengontrol perubahan-perubahan yang terjadi selama proses pengembangan.

\section{Bahan dan Metode}

\subsection{Bahan}

\section{A. Sistem}

Sistem adalah suatu kesatuan utuh yangterdiri dari beberapa bagian yang saling berhubungan dan berinteraksi untuk mencapai tujuan tertentu."(Manurung, 2019).

Sistem adalah kumpulan orang yang saling bekerja sama dengan ketentuanketentuan aturan yang sistematis dan terstruktur untuk membentuk satu kesatuan yang melaksanakan fungsi untuk mencapai tujuan”(Anggraeni \& Irviani, 2017).
Suatu sistem terdiri dari beberapa subsistem atau komponen sistem lain yangsaling berhubungan membentuk satu kesatuan sehingga tujuan atau sasaran dapat tercapai(Aziz, 2018).

Dapat disimpulkan jika sistem adalah kesatuan yang terdiri dari kumpulan orang, bagian, maupun subsistem yang saling berinteraksi secara sistematis dan terstruktur dengan aturan tertentu yang melaksanakan fungsi untuk mencapai tujuan yang diharapkan

\section{B. Informasi}

Dalam pengambilan keputusan, diperlukan sebuah informasi yang menggambarkan suatu kejadian yang berasal dari data-data yang sudah diolah (Manurung, 2019).

Data merupakan sumber informasi, data biasa disebut fakta atau kenyataan yang menggambarkan suatu peristiwa atau kejadian yang memiliki suatu arti (Widodo \& Imam, 2016).

\section{Sistem Informasi}

Sistem informasi adalah suatu sistem didalam suatu organisasi yang mempertemukan kebutuhan pengelolaan transaksi harian, mendukung operasi, bersifat manajerial, dan kegiatan strategi dari suatu organisasi dan menyediakan pihak luar tertentu dengan laporan- laporan yang dibutuhkan. (Arif, 2019). 


\section{Unified Approach}

Unifed Approach adalah salah satu metodologi pengembangan sistem berbasis objek yang menggabungkan proses dan metodologi yang telah ada sebelumnya dan menggunakan UML pada pemodelannya (Bahrami, 1999).

\section{E. Unified Modeling Language (UML)}

UML adalah sebuah teknik pengembangan sistem yang menggunakan bahasa grafis sebagai alat untuk pendokumentasian dan melakukan spesifikasi pada sistem(Mulyani, 2016).

\subsection{Metode Penelitian}

\section{A. Metode Unified Approach}

Metode yang digunakan pada tahapan ini yaitu menggunakan Metode Unified Approach dengan 2 tahapan utama yaitu Object Oriented Analysis (OOA) dan Object Oriented Design (OOD), dengan tahapan sebagai berikut:

1. Object Oriented Analysis (OOA)

Analisis adalah proses menyaring kebutuhan sistem lain dan apa yang harus dilakukan sistem untuk memenuhi kebutuhan aktor (Bahrami, 1999).

Tahapan yang harus dilakukan pada metode unifed approach sebagai berikut:

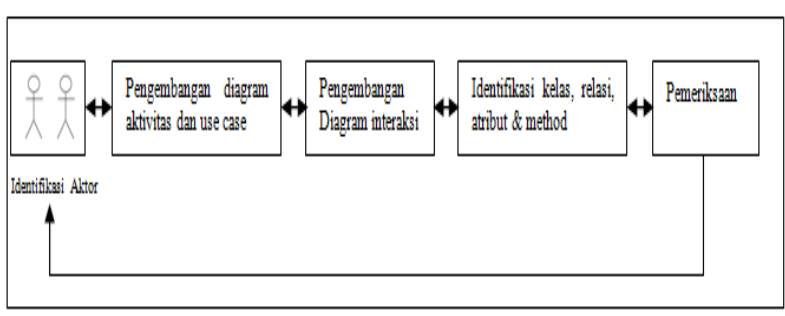

Gambar 1. Tahap Analisis Unified Approach

2. Object Oriented Design (OOD)

Hasil dari tahap analisis sebelumnya digunakan untuk merancang sebuah sistem. Tujuannya agar memberikan gambaran yang jelas untuk memudahkan programmer dalam proses pembuatan perangkat lunak atau sistem informasi, dengan tahapan sebagai berikut:

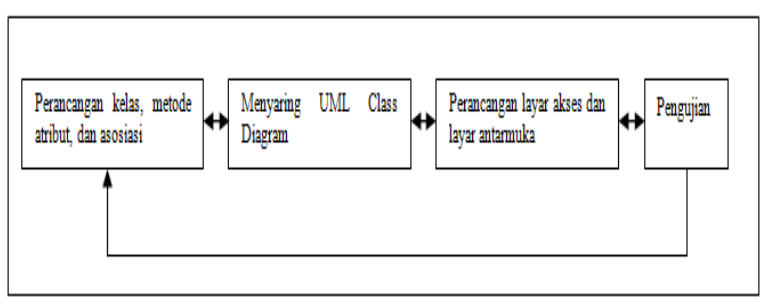

Gambar 2 : Tahap Perancangan Unified Approach (UA)

\section{Hasil dan Diskusi}

Penelitian ini menggunakan metode Unified Approach (UA) yang pemodelannyamenggunakan rancangan diagram-diagram dari UML yang menggambarkan alur dari perancangan sistem dimulai dari Activity Diagram, Usecase Diagram dan Sequance Diagram. Hal ini sangat penting karena dalam 
merancang sebuah sistem harus berdasarkan kebutuhan-kebutuhan sistem dan pengguna yang digambarkan dalam sebuah diagram UML. Referensi penelitian yang dilakukan oleh Fadhilah dkk (2017) menggunakan metode Waterfall yang hanya menggambarkan Data Flow Diagram pada rancangan sistemnya, sedangkan pada penelitian ini kami menggunakan UML untuk memudahkan dalam merancangan sistem hasil penelitian.

Berikut di bawah ini diagram UML hasil penelitian:

\subsection{Activity Diagram}

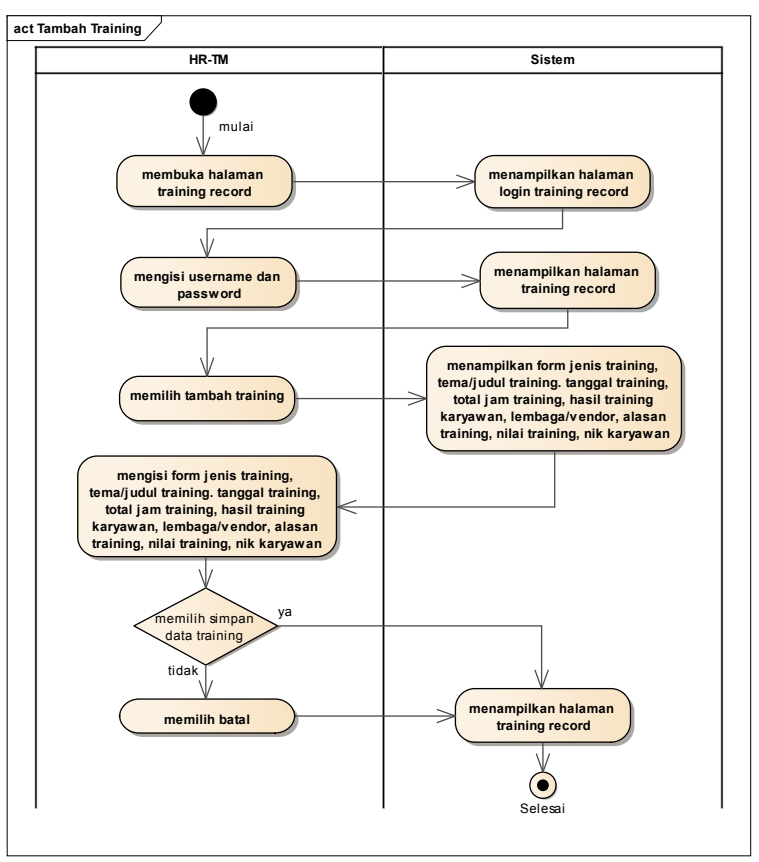

Gambar 3 :Activity Diagram Tambah

Training Baru Oleh HR-TM

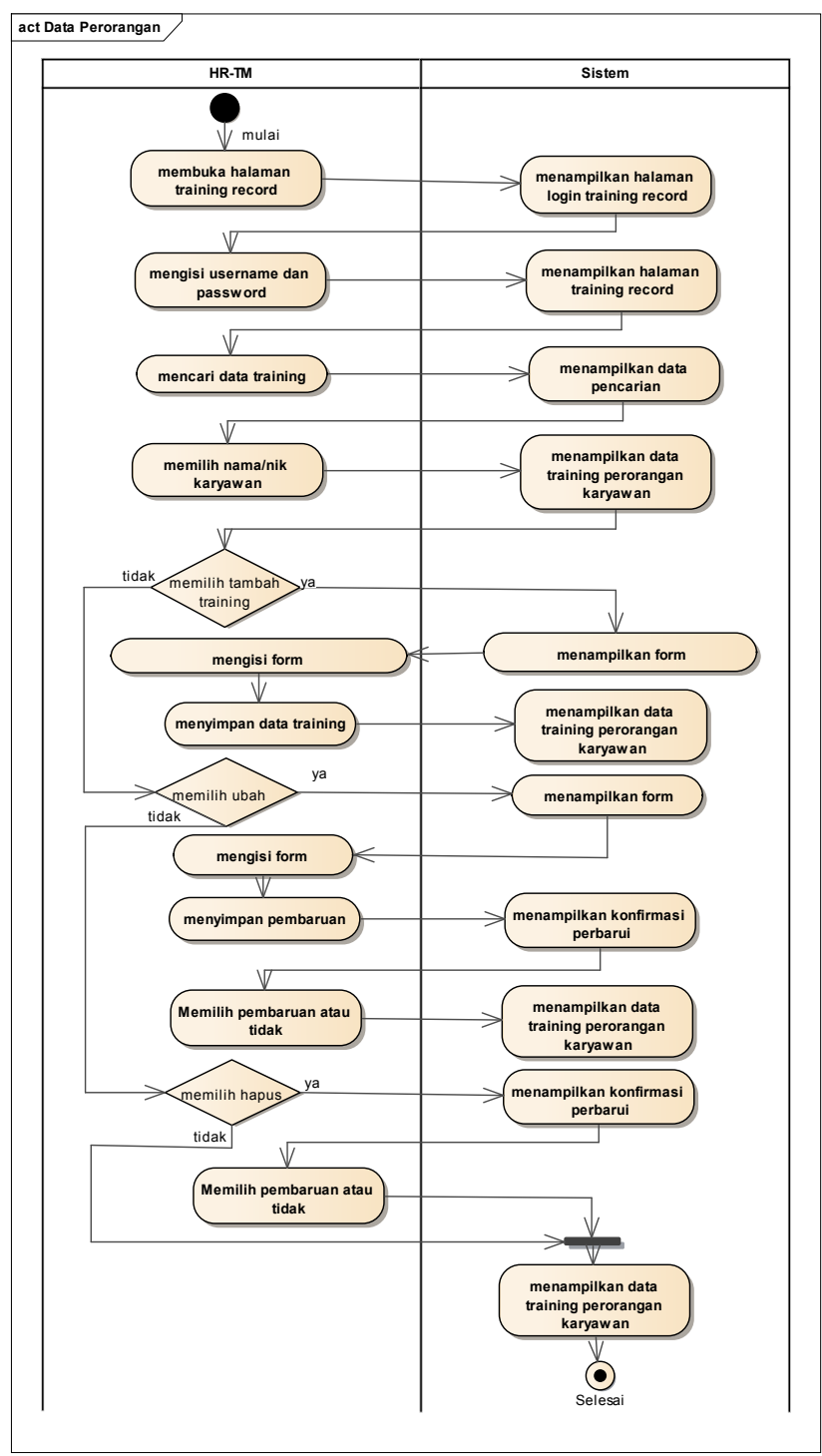

Gambar 4 :Activity Diagram Tambah, Ubah, dan Hapus Training PeroranganOleh HR-TM 


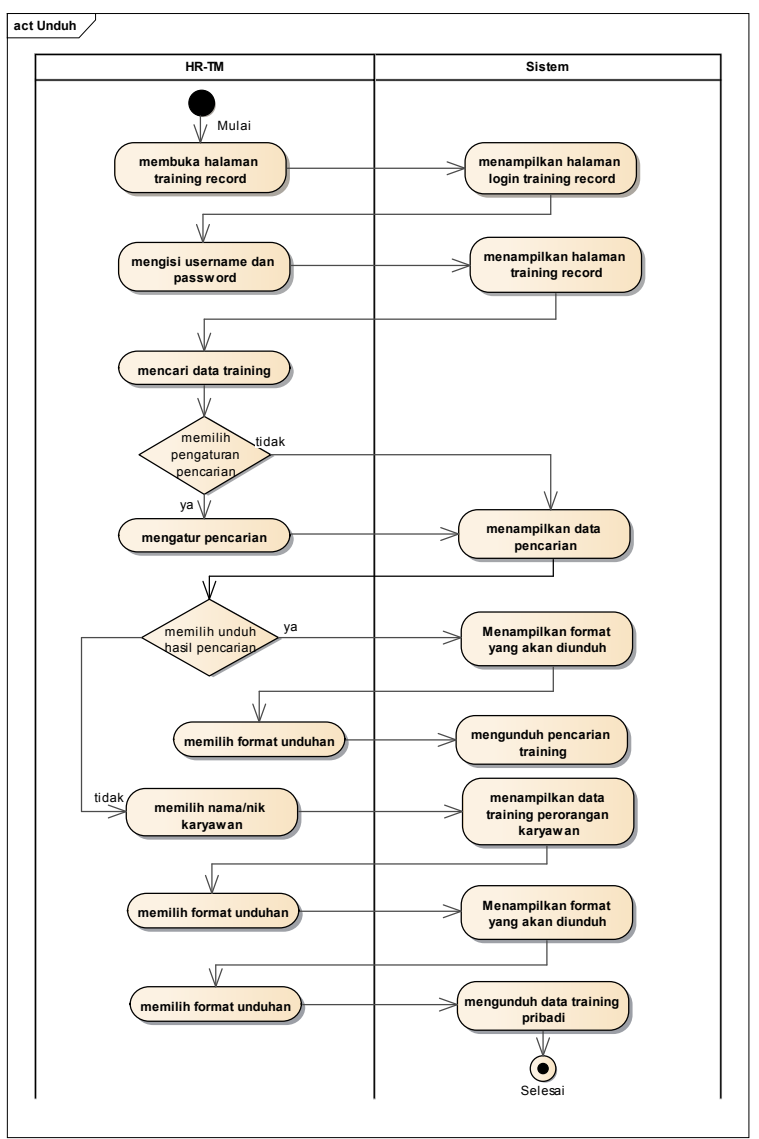

Gambar 5 :Activity Diagram Unduh Data

Training Oleh HR-TM

\subsection{Use Case Diagram}

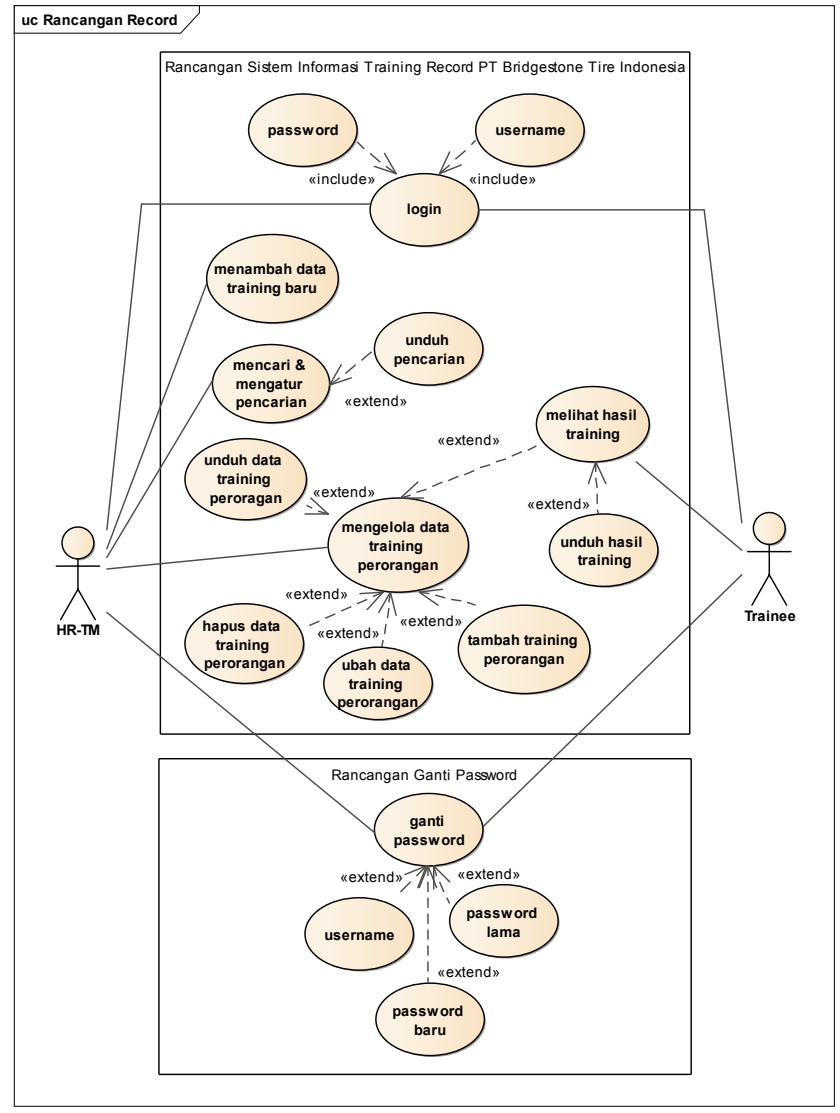

Gambar 8 : Use Case Diagram Rancangan

Sistem Training Record 


\subsection{Sequence Diagram}

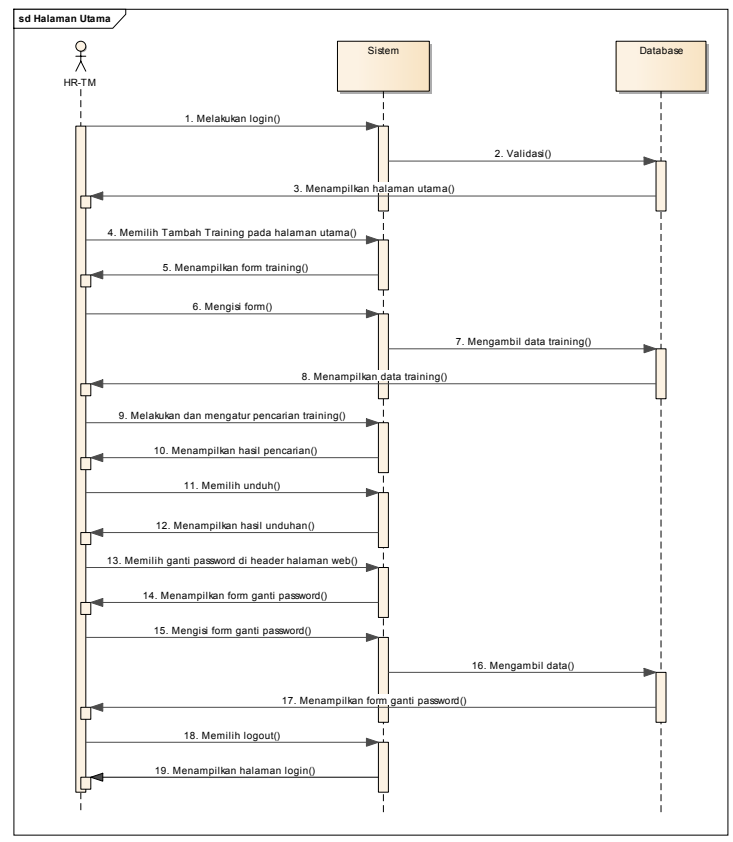

Gambar 9 : Rancangan Sequence Diagram

Halaman Utama oleh HR-TM

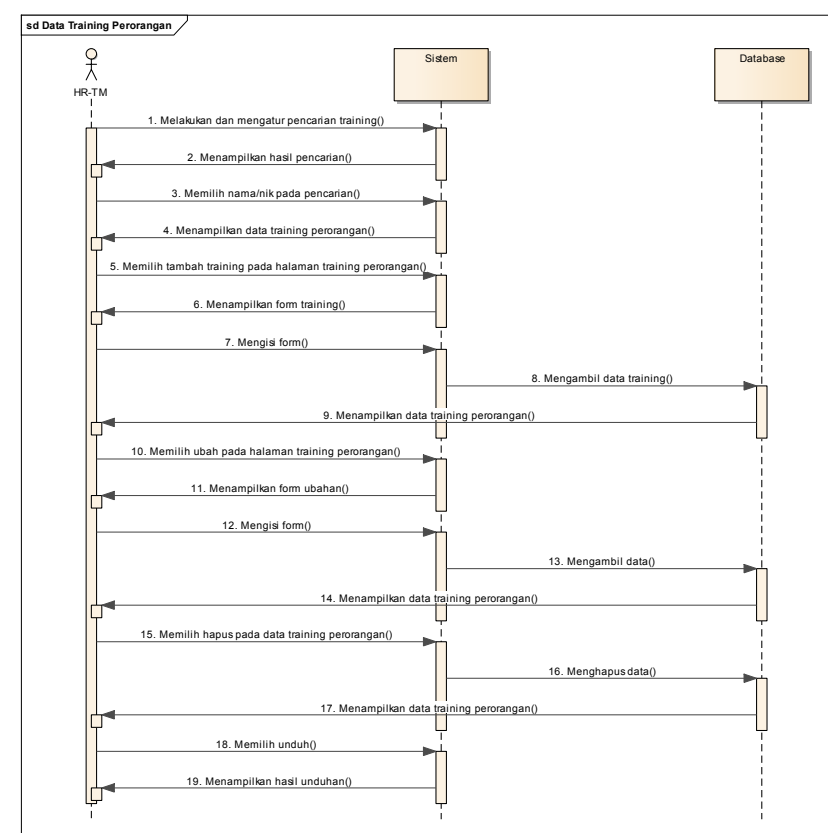

Gambar 10 : Rancangan Sequence Diagram
Halaman Training Perorangan oleh HR-TM

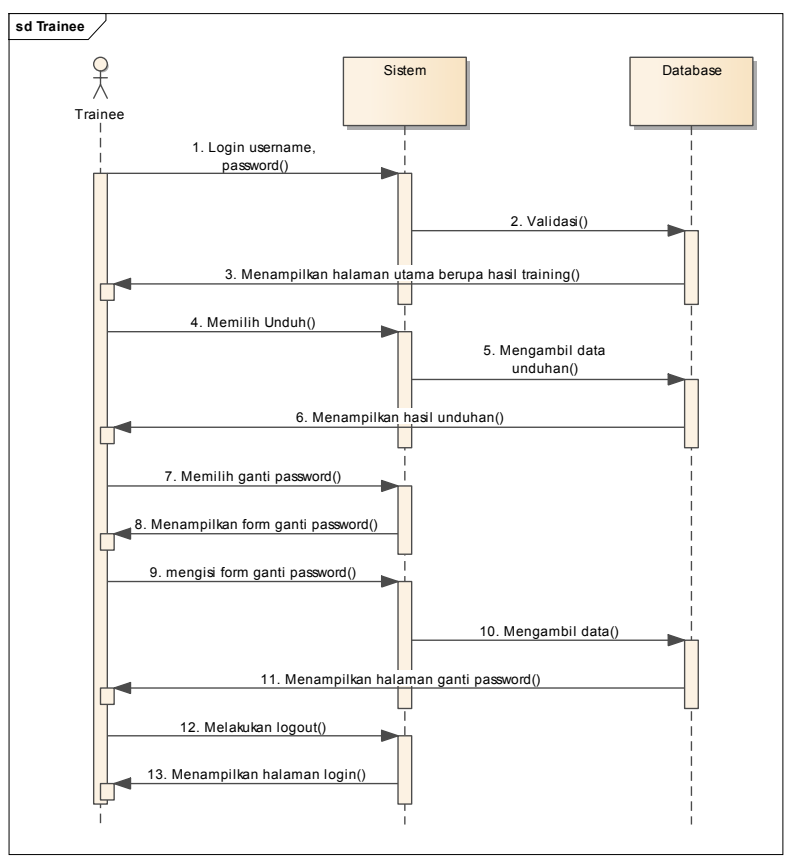

Gambar 11 : Rancangan Sequence

Diagram oleh Trainee

\subsection{Identifikasi Class, Atribute, Method}

Tabel 1. Identifikasi Class, Atribute, Method

\begin{tabular}{|c|c|c|}
\hline Class & Attribut & Method \\
\hline HR_TM & $\begin{array}{l}\text { Username, } \\
\text { NIK_TM, } \\
\text { nama, seksi, } \\
\text { dept, plant, } \\
\text { password, } \\
\text { email }\end{array}$ & $\begin{array}{l}\text { Tambah, } \\
\text { Ubah, } \\
\text { Simpan, } \\
\text { Hapus }\end{array}$ \\
\hline Trainee & $\begin{array}{l}\text { NIK, nama, } \\
\text { seksi, dept, } \\
\text { plant, } \\
\text { password, } \\
\text { email }\end{array}$ & $\begin{array}{l}\text { Tambah, } \\
\text { Ubah, } \\
\text { Simpan, } \\
\text { Hapus }\end{array}$ \\
\hline
\end{tabular}




\begin{tabular}{|l|l|l|}
\hline Training & Id_training, & Tambah, \\
kd_training, & Ubah, \\
thema, & Simpan, \\
tgl_awal, & Hapus \\
tgl_akhir, & \\
totaljam, & kd_result, \\
lembaga, & \\
tempat, alasan, & \\
pre_test, \\
post_test, \\
job_history, \\
cost_amount, \\
username, nik
\end{tabular}

\subsection{Logical Record Structure}

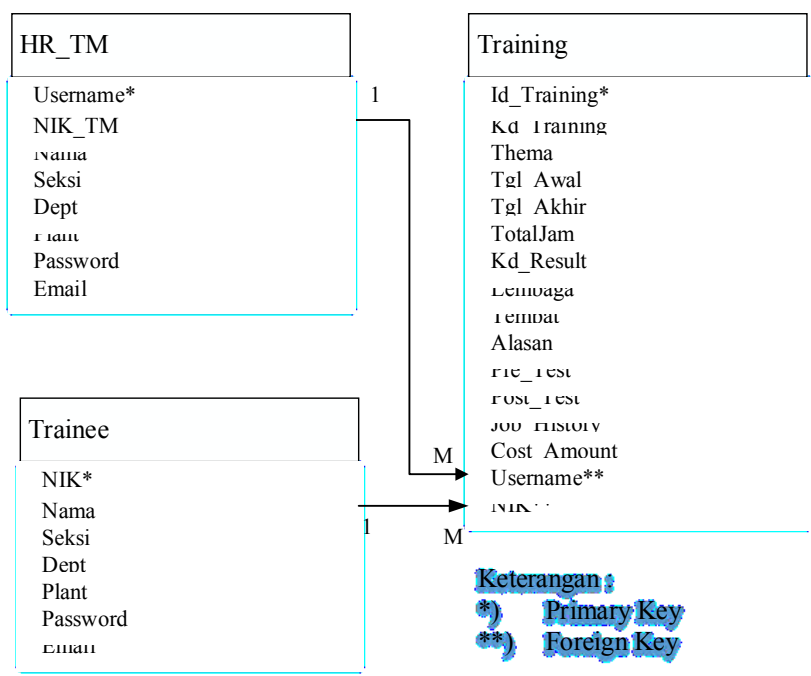

\subsection{Prototype}

a. Halaman Login

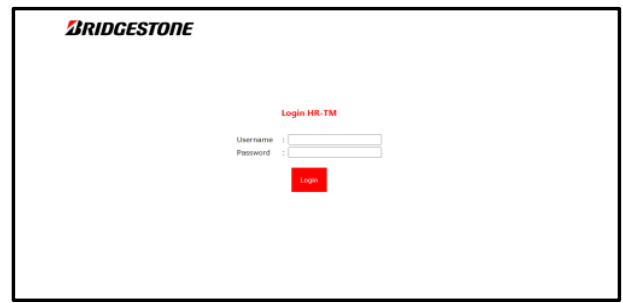

b. Halaman Utama HR-TM

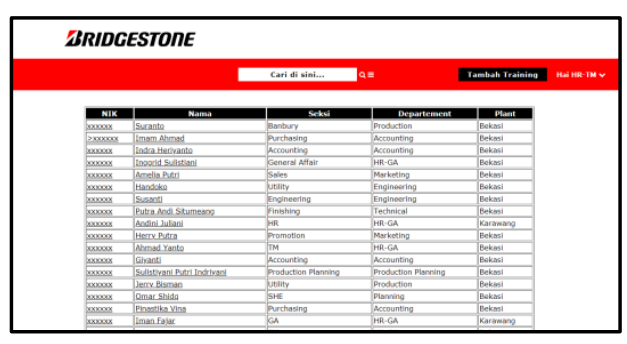

\section{Gambar : Rancangan Prototype Halaman}

\section{Utama Oleh HR-TM}

c. Halaman Tambah Training Baru

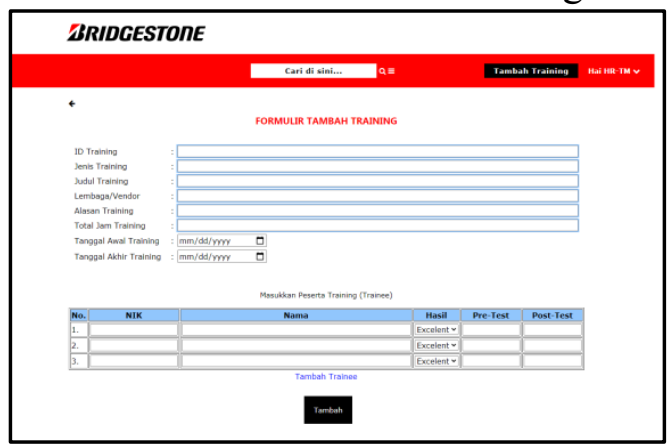

Gambar : Rancangan Prototype Tambah Training Baru Oleh HR-TM

Gambar 12 :Logical Record Structure 


\section{d. Halaman Pencarian}

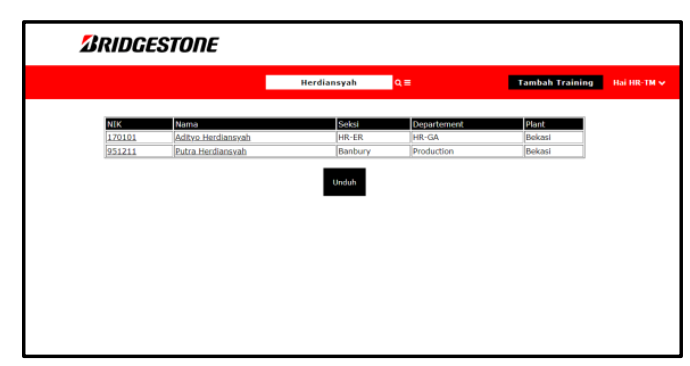

Gambar : Rancangan Prototype Pencarian Oleh HR-TM

e. Halaman Atur Pencarian

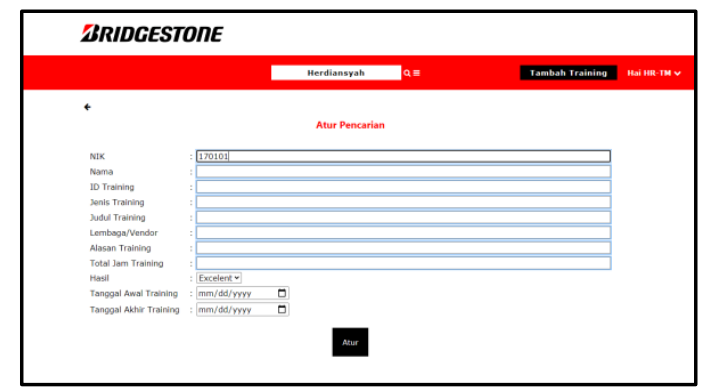

Gambar : Rancangan Prototype Atur Pencarian Oleh HR-TM

f. Halaman Data Training Perorangan

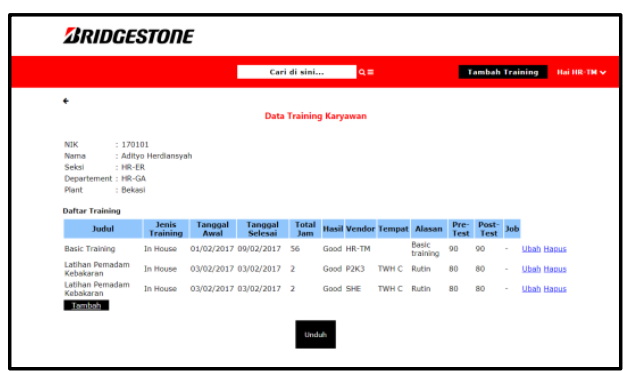

Gambar : Rancangan Prototype Data

Training Perorangan Oleh HR-TM g. Halaman Tambah Training

Perorangan

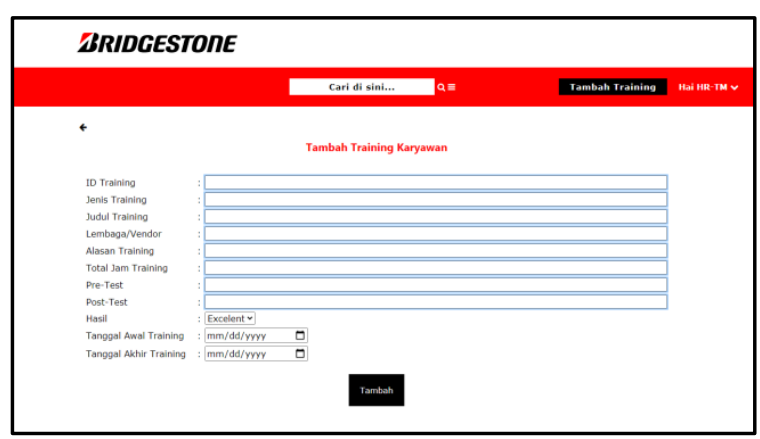

Gambar : Rancangan PrototypeForm

Tambah Training Perorangan Oleh HR-

TM

h. Halaman Utama Trainee

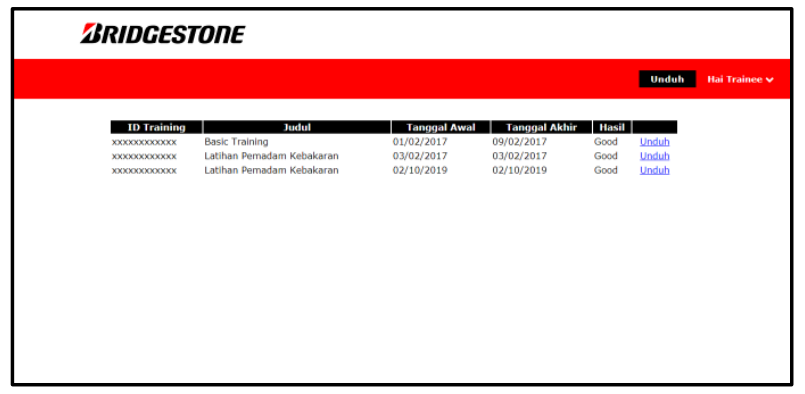

\section{Gambar : Rancangan Prototype Halaman}

\section{Utama Oleh Trainee}

\section{Kesimpulan}

Berdasarkan analisis sistem trainingrecord pada PT Bridgestone Tire Indonesia yang sudah dilakukan, dapat disimpulkan bahwa kegiatan training record menjadi lebih efektif dalam pengelolaan data pelatihan, hal tersebut sudah menggunakan sistem informasi yang dapat mengelola manajemen data yang baik 


\subsection{Ucapan Terima Kasih}

Alhamdulillah puji dan syukur kami panjatkan kepada Allah swt karena berkat rahmat dan hidayahnya kami bisa menyelesaikan penelitian ini. Kami juga mengucapkan terima kasih kepada PT. Bridgestone Tire Indonesia yang telah memberikan izin dan dukungan kepada kami dalam melakukan penelitian ini.

\subsection{Referensi}

Anggraeni, E. Y., \& Irviani, R. (2017). Pengantar Sistem Informasi. Yogyakarta: Andi.

Arif, M. F. (2019). Analisis dan Perancangan Sistem Informasi. Surabaya: Penerbit Qiara Media.

Aziz, I. (2018). Pengaruh Penggunaan Sistem Teknologi Informasi Dan Persepsi Mitra Kerja (Satker) Terhadap Modul Penerimaan Negara Generasi Ke II (Mpn G2) Pada KPPN Makassar II. 441-452. Diambil dari https://ejurnal.stienobel-

indonesia.ac.id/index.php/akmen/article /view/316/320

Fadhilah, F.G., Wahyudiono, S., \& Waluyo, S. (2017). Sistem Informasi Pelatihan Di Balai Latihan Kerja Kabupaten Magelang. Jurnal Informasi \& Pengembangan Iptek (STMIK Bina Patria)

Fatmawati, Ferryanto, Adiwihardja. C.
(2018). Perancangan Sistem Informasi Pengolahan Data dan Pengarsipan Menggunakan Model Waterfall. Jurnal Speed, 10(1), 1-6

Herdiansyah, Adityo, interview by Lily Ciptaningrum. 2019. Pembuatan Sistem Informasi Training Record.

Mahmudah. S, Widiastuti. L \& Ernawati. S. (2019). Sistem Informasi Manajemen Pengarsipan Surat Masuk Dan Surat Keluar (Studi Kasus : Ma Darul Ihya Bogor). Jurnal Media Informatika Budidarma, 3(3), 225-231.

Manurung, I. H. G. (2019). Sistem Informasi Lembaga Kursus Dan Pelatihan (LKP) City Com Berbasis Web Menggunakan PHP Dan MYSQL. Jurnal Mahajana Informasi, 4(1), 42-50.

Mulyani, S. (2016). Metode Analisis dan Perancangan Sistem. Bandung: Abdi Sistematika.

Sutikno, R. B. (2018). HR Division It's Scope Of Works: Personnel Administration + Training \& Development + General Affair. Yogyakarta: Deepublish.

Widodo, P., \& Imam, I. (2016). Perancangan Website Pertanian Di Ploso Gede Ngluwar Magelang Sebagai Media Informasi Dan Pemasaran (Studi Kasus Pada Kelompok Tani Hidayah). Journal Speed - Sentra Penelitian Engineering Dan Edukasi, 10(4), 14 
31. Diambil dari

https://repository.bsi.ac.id/index.php/re

po/viewitem/14048 